\title{
CYP1A2 Gene Polymorphism and Theophylline Level in Asthma
}

\author{
Amelia Lorensia ${ }^{1, *}$, Zullies Ikawati ${ }^{2}$, Tri Murti Andayani ${ }^{2}$, Daniel Maranatha ${ }^{3}$, Mariana Wahyudi ${ }^{4}$ \\ ${ }^{1}$ Department of Clinical Pharmacy-Community, Faculty of Pharmacy, Universitas Surabaya, Jl. Raya Kalirungkut, Surabaya, Indonesia \\ ${ }^{2}$ Department of Pharmacology and Clinical Pharmacy, Faculty of Pharmacy, Universitas Gadjah Mada, Jl. Farmako Sekip Utara, Yogyakarta, Indonesia \\ ${ }^{3}$ Department of Pulmonology and Respiratory Medicine, Faculty of Medicine, University of Airlangga/General Hospital Dr. Soetomo, \\ Jl. Mayjen Prof. Dr. Moestopo No.47, Surabaya, Indonesia \\ ${ }^{4}$ Department of Purification and Molecular Biology, Faculty of Biotechnology, Universitas Surabaya, Jl. Raya Kalirungkut, Surabaya, Indonesia \\ *Corresponding author. E-mail: amelia.lorensia@staff.ubaya.ac.id
}

Received date: Jun 11, 2018; Revised date: Oct 12, 2018; Accepted date: Oct 16, 2018

\section{Abstract}

B ACKGROUND: Aminophylline (theophylline) is one of the most frequent asthma therapies in Indonesia, although it remains as a narrow therapy. The effects of drugs are individualized and strongly influenced by genetic, one of which is CYP1A2 gene polymorphisms. This study aimed to determine the profile of CYP1A2 polymorphism and theophylline level in asthma exacerbation patients receiving intravenous aminophylline therapy.

METHODS: This cross sectional study was conducted in the emergency room (ER), to adults asthma exacerbation patients without complication ( $\mathrm{n}=27)$, visiting the ER. The gene polymorphism data were compared with theophylline levels in the blood using chi-square test.
RESULTS: In the CYP1A2 gene polymorphism profile, the most common heterozygous alleles are $\mathrm{T} / \mathrm{G}$ genotype of $C Y P 1 A 2 * 1 E$ and C/A genotype of CYP1A2*1F. Most homozygote alleles exist in $C Y P 1 A 2 * 1 D$ and $C Y P 1 A 2 * 1 F$. There was significant difference between $C Y P 1 A 2 * 1 D$ $(p<0.005), \quad C Y P 1 A 2 * 1 E \quad(p<0.023)$ and $C Y P 1 A 2 * 1 F$ $(p<0.000)$ polymorphisms and theophylline level.

CONCLUSION: $\quad C Y P 1 A 2 * 1 D, \quad C Y P 1 A 2 * 1 E$ and $C Y P 1 A 2 * 1 F$ gene polymorphisms had an effect on theophylline levels. However, no one experienced an overdose theophylline, and no correlation between theophylline levels with CYP1A2 gene polymorphism.

KEYWORDS: exacerbation asthma, intravenous aminophylline, CYP1A2 polymorphism gene, theophylline

Indones Biomed J. 2019; 11(1): 63-9

\section{Introduction}

Asthma is a heterogeneous disease and one of the major health problems in the world.(1) Asthma is a chronic inflammatory disorder of the airways, with many cells and cellular elements playing a role.(1,2) Worsening asthma symptoms can worsen asthma exacerbation and decrease in lung function.(1) Exacerbations of asthma is important because it is associated with patient's quality of life as well as substantially increased spending on health system. (3) Asthma is included in the top 10 non-communicable diseases in Indonesia.
Aminophylline (prodrug of theophylline) is used for the treatment of exacerbations of asthma (1), including in Indonesia. In Indonesia, aminophylline/theophylline and aminophylline are included in the Indonesian National Essential Medicines List in 2015 until now.(4,5) Theophylline and aminophylline prices on the market tend to be affordable and they are available as over-thecounter (OTC) that can be used without prescription by a doctor, so the effects of drugs cannot be monitored by health professionals. Although beta-2 agonist is the first line for asthma exacerbations (1), previous studies have concluded there is no difference in effectiveness between beta-2 agonist and aminophylline. A study on randomized 
controlled trial published by Travers, et al., said there is no consistent evidence for the use of intravenous beta-2 agonist or intravenous aminophylline for exacerbations asthma.(6) Previous research reported that while there was no difference in the effectiveness of salbutamol (beta-2 agonist) and aminophylline in the first 2 hours, aminophylline significantly reduced the length of hospital stay.(7) Small doses of theophylline is known to not only relax the airway smooth muscle, but also has antiinflammatory and immunomodulatory effects, which is the basic pharmacology theory for asthma treatment.(8)

In Indonesia, aminophylline is frequently used as primary therapy of asthma exacerbations in the hospital because it is effective and rarely causes adverse drug reaction (ADR) events even when taken in conjunction with other asthma treatment.(9-12) Even when the safety of aminophylline compared to salbutamol showed there were no significant difference in hypokalemia and hypernatremia event.(13) Although the use of theophylline/aminophylline has been abandoned, because it is drug with narrow therapeutic index and the potential causes of ADR.(14) That many studies have proven ADR avent from the use of aminophylline in abroad.(15-19)

Effects of aminophylline can be caused by individual characteristics. Genetic factors are the main factors that cause different response to asthma therapy $(20,21)$ and drug response can be determined by the relationship between genotypes (22-25).

Pharmacogenetic profile in theophylline need to be further investigated to describe the pharmacogenetic profile Indonesia people associated with metabolism of theophylline pharmacokinetics.(26) Polymorphisms associated with CYP (Cytochrome) P450 have been studied previously.(22-25) Theophylline is metabolized by CYP450 and CYP1A2 gene polymorphism proven to influence theophylline drug levels in the blood, on CYP1A2 on CYP1A2*1C, CYP1A2*1D, $C Y P 1 A 2 * 1 E$ and $C Y P 1 A 2 * 1 F .(22-25)$ Previous studies have shown Asian subjects tend to be poor metabolism for certain drugs and therefore more at risk of adverse events, for example Asian subjects have greater drug sensitivity than Caucasian in the use of several other drugs, such as warfarin (27), propranolol (28) and morfin (29). In Asia in Indonesia, previous studies have shown that theophylline is eliminated faster than other populations, which require more frequent theophylline doses.(30) The most ethnic in Indonesia is Java, that most have $C Y P 1 A 2 * 1 F$ polymorphism gene.(30) A genotype at $C Y P 1 A 2 * 1 F$ allele is associated with fast metabolism, compared with genotype C. Therefore, the
A/A genotype of $C Y P 1 A 2 * 1 F$ has a faster metabolism than $\mathrm{C} / \mathrm{C}$ or $\mathrm{C} / \mathrm{A}$, thus causing lower drug levels.(31) This study aimed to determine the profile of CYP1A2 polymorphism and theophylline level in blood in asthma exacerbation patients receiving intravenous aminophylline therapy.

\section{Methods}

\section{Design Research}

This was a cross-sectional study. The research variables include polymorphism of CYP1A2 gene and theophylline level in blood. Subjects received intravenous aminophylline therapy, slowly with a slow bolus of $6 \mathrm{mg} / \mathrm{kg}$ for 20 minutes, followed by infusion $(0.9 \% \mathrm{NaCl})$ at $5 \mu \mathrm{g} / \mathrm{kg} / \mathrm{hr}$. Theophylline $1 \mathrm{mg}$ is equivalent to 1:25 $\mathrm{mg}$ aminophylline. (32-34) This study was conducted from January 2014 to June 2016.

\section{Subject}

The population was all patients with exacerbations of asthma with Java race in a hospital in Surabaya. Research subjects were all patients with asthma exacerbations in all hospitals in Surabaya who meet the inclusion and exclusion criteria of the study. The inclusion criteria of the research subjects included: (i) patients aged $\geq 18$ years; (ii) consent to become a subject of research; (iii) the level of mild-moderate asthma exacerbations, because at that level corticosteroid or other asthma therapies should not be added, and patients with severe exacerbations of asthma at a rate of up to lifethreatening need additional therapy such as anticholinergic and ccorticosteroids (1) that could affect the study results. Exclusion criteria research subjects were: (i) patients who use contraception; (ii) the pregnant or lactating patient; (iii) patients with chronic renal function impairment; (iv) patients with chronic liver disease; (v) patients who smoked or quit smoking $<2$ years; (vi) patients consuming coffee; and (vii) patients admitted to getting asthma exacerbation therapy before coming to the emergency room, because the other therapy can increase risk of ADR event or drug interactions.

Sampling methods used in the study was consecutive sampling since there were no subject frames, only selected according to inclusive and exclusion criteria. Subjects which was selected were those who came to the hospital dcertain period. In this study, the population of unknown size as was asthma exacerbations in a hospital in Surabaya. Then it was assumed that the general population was not known, based 
Table 1. Location of polymorphism and length of PCR product, as well as the endonuclease restriction on PCR-RFLP.(24)

\begin{tabular}{|c|c|c|c|}
\hline $\begin{array}{l}\text { Polymorphic Sites } \\
\text { at } C Y P 1 A 2\end{array}$ & Primers & Primers Position & $\begin{array}{l}\text { PCR Product } \\
\text { Length (bp) }\end{array}$ \\
\hline \multirow{2}{*}{$(\mathrm{G} / \mathrm{A}) C Y P 1 A 2 * 1 C$} & F: 5'- GCT ACA CAT GAT CGA GCT ATA C -3' & $-3097 \rightarrow-3076$ & \multirow{2}{*}{598} \\
\hline & R: 5'- CAG GTC TCT TCA CTG TAA TGT TA -3' & $-2500 \leftarrow-2520$ & \\
\hline \multirow{2}{*}{$(\mathrm{t} / \mathrm{del}) C Y P 1 A 2 * 1 D$} & F: 5’- TGA GCC ATG ATT GTG GCA TA -3’ & $-1589 \rightarrow-1570$ & \multirow{2}{*}{167} \\
\hline & R: 5'- AGG AGT CTT TAA TAT GGA CCC AG -3' & $-1423 \leftarrow-1445$ & \\
\hline \multirow{2}{*}{ (T/G) $C Y P 1 A 2 * 1 E$} & F: 5'- AAA GAC GGG GAG CCT GGG CTA GGT GTA GGA G -3' & $124 \rightarrow 154$ & \multirow{2}{*}{169} \\
\hline & R: 5’- AGC CAG GGC CAG GGC TGC CCT TGT GCT AAG -3’ & $292 \leftarrow 263$ & \\
\hline \multirow{2}{*}{$(\mathrm{C} / \mathrm{A}) C Y P 1 A 2 * 1 F$} & F: 5'- CCC AGA AGT GGA AAC TGA GA -3' & $613 \rightarrow 623$ & \multirow{2}{*}{243} \\
\hline & R: 5'- GGG TTG AGA TGG AGA CAT TC -3' & $855 \leftarrow 836$ & \\
\hline
\end{tabular}

on the formula of Medical Statistics calculating (35), then most minimal research subjects each group in this study was 26 people.

\section{CYP1A2 Polymorphism Determination}

The polymerase chain reaction-restriction fragment length polymorphism (PCR-RFLP) technique was used to identify DNA genomic polymorphisms in the 5-flanking region and the first intron of the $C Y P 1 A 2$ gene. The steps consisted of amplification of determinants of CYP1A2 gene polymorphism and RFLP analysis.

DNA of each subject was extracted using GenElute Blood Genomic DNA Kit and used as the PCR reaction template. There were 4 PCR reactions that will be carried out for each subject, with 4 pairs of primers. PCR reaction was carried out in the PCR reaction mixture with GoTaqGreen 2x Master mix PCR (Promega, Fitchburg, USA) according to the product protocol, on PCR (Perkin Elmer, Waltham, USA) machine with the following conditions: predenaturation at $95^{\circ} \mathrm{C}$ for 12 minutes, denaturation at $95^{\circ} \mathrm{C}$ for 1 minute, annealing temperature of $57^{\circ} \mathrm{C}$ for 1 minute, and extension at $72^{\circ} \mathrm{C}$ for 40 seconds, as many as 40 cycles. PCR products were electrophoresed on $3 \%$ agarose gel, with predictions of each PCR product size as shown in Table 1.

The PCR products were cut with DdeI, NdeI, StuI, or ApaI restriction enzymes, respectively. Polymorphism is characterized by whether or not PCR products are cut by restriction enzymes as shown in Table 2.

\section{Method of Collecting Data}

Examination of theophylline level in blood was done after administration of aminophylline therapy for one hour. Five $\mathrm{mL}$ of blood was taken from the subject by nurse/laboratory officer in an ependorf tube. Plasma and serum was separated using centrifugation and kept cool with temperature $2-8^{\circ} \mathrm{C}$. Theophylline level was measured in a laboratory by using chemiluminescent microparticle immunoassay (CMIA) method. This study has obtained ethical licenses with numbers 01/EC/KERS/2014.

\section{Data Analysis}

Genetic examination was carried out at the Purification Laboratory and Molecular Biology, Faculty of Biotechnology, Universitas Surabaya, which is located on Kalirungkut Tenggilis Highway in Surabaya, which is in accordance to the ISO (International Organization for Standardization) standard.

Once all the data is collected, the gene polymorphism data was presented descriptively. The theophylline levels in the blood data was observed between different $C Y P 1 A 2$ gene polymorphism with a chi-square test to see the relationship between them.

Table 2. Determination of the type of product PCR fragment for RFLP analysis.

\begin{tabular}{ccccc}
\hline $\begin{array}{c}\text { Polymorphic Sites } \\
\text { at } \text { CYP1A2 }\end{array}$ & $\begin{array}{c}\text { PCR Product } \\
\text { Length (bp) }\end{array}$ & $\begin{array}{c}\text { Restriction } \\
\text { Enzymes }\end{array}$ & Result & Allele \\
\hline (G/A) $C Y P 1 A 2 * 1 C$ & 598 & Dde I & $\begin{array}{c}(+) \\
(-)\end{array}$ & $\mathrm{G}$ \\
\hline (t/del) $C Y P 1 A 2 * 1 D$ & 167 & Nde I & $(+)$ & $\mathrm{T}$ \\
& & & $(-)$ & $\mathrm{del}$ \\
\hline & 169 & $S t u \mathrm{I}$ & $(+)$ & $\mathrm{G}$ \\
$(\mathrm{T} / \mathrm{G}) C Y P 1 A 2 * 1 E$ & & & $(-)$ & $\mathrm{T}$ \\
\hline & 243 & $A p a \mathrm{I}$ & $(+)$ & $\mathrm{C}$ \\
$(\mathrm{C} / \mathrm{A}) C Y P 1 A 2 * 1 F$ & & & $(-)$ & $\mathrm{A}$ \\
\hline
\end{tabular}

$(+)$ : can be cut with restriction enzymes; $(-)$ : cannot be cut with restriction enzymes. 


\section{Results}

The study was involving 27 research subjects and the description of subjects can be seen in Table 3 . None of the study subjects have an accompanying disease.

\section{Frequency Distribution of $C Y P 1 A 2$ Gene Polymorphism}

It was known that most heterozygous alleles are $\mathrm{T} / \mathrm{G}$ genotypes of $C Y P 1 A 2 * 1 E(81.48 \%)$ and C/A genotype of $C Y P 1 A 2 * 1 F(77.78 \%)$, whereas most homozygous alleles belong to study subjects were $\mathrm{G} / \mathrm{G}$ genotype of $C Y P 1 A 2 * 1 C$ $(85.19 \%)$ and $\mathrm{T} / \mathrm{T}$ genotype of $C Y P 1 A 2 * 1 D(70.37 \%)$. In the profile of $C Y P 1 A 2$ polymorphism gene was found mutant genotype, which was in $C Y P 1 A 2 * 1 C$. Meanwhile, in $C Y P 1 A 2 * 1 E$ polymorphism was not found any $\mathrm{G} / \mathrm{G}$ genotype (Table 4).

\section{Theophylline Content Profile after Intravenous Aminophylline for 1 Hour}

Theophylline levels in the blood in all study subjects who received intravenous aminophylline therapy did not have overdose, and most were in the normal range. The normal level of theophylline therapy in the blood is $10-15 \mathrm{mg} / \mathrm{L}$ (56-83 $\mu \mathrm{mol} / \mathrm{L})$. although improvement in lung function can be observed at $5 \mathrm{mg} / \mathrm{L}$ concentration $(28 \mu \mathrm{mol} / \mathrm{L})$ while toxicity increases at $>20 \mathrm{mg} / \mathrm{L}$. All of the study subjects did

Table 3. Characteristic of subjects using aminophylline intravenous and nebulized salbutamol group.

\begin{tabular}{llcc}
\hline \multirow{2}{*}{ Characters Baseline } & \multicolumn{2}{c}{$\begin{array}{c}\text { Intravenous Aminophylline } \\
\text { Group (n=27) }\end{array}$} \\
\cline { 3 - 4 } Gender & Female & $\mathbf{n}$ & $\mathbf{( \% )}$ \\
\hline \multirow{3}{*}{ Age (years) } & Male & 14 & 51.85 \\
& Late adolescence (17-25) & 5 & 18.52 \\
& Early adult (26-35) & 5 & 18.52 \\
& Early elderly (46-55) & 8 & 29.63 \\
& Late elderly (56-65) & 2 & 7.41 \\
& Average & 70.11 & \\
\hline \multirow{3}{*}{ Employment (36-45) } & 10 & 37.04 \\
& Household assistant & 10 & 33.34 \\
& Entrepreneur & 9 & 14.81 \\
& Employee & 4 & 14.81 \\
\hline
\end{tabular}

$p$-value $>0.05$, means there is no difference between the two groups.
Table 4. Frequency distribution of CYP1A2 gene polymorphisms on intravenous aminophyllline.

\begin{tabular}{|c|c|c|c|c|}
\hline \multirow{2}{*}{$\begin{array}{l}\text { CYP1A2 Genetic } \\
\text { Polymorphism }\end{array}$} & \multirow{2}{*}{ Genotype } & \multirow{2}{*}{ Phenotype } & \multicolumn{2}{|c|}{ Total $(n=27)$} \\
\hline & & & $\mathbf{n}$ & $\%$ \\
\hline \multirow{3}{*}{$\begin{array}{l}C Y P 1 A 2 * 1 C \\
(-2964 \mathrm{G}>\mathrm{A})\end{array}$} & $\mathrm{G} / \mathrm{G}$ & Wild-type & 23 & 85.19 \\
\hline & $\mathrm{G} / \mathrm{A}$ & Heterozygous & 3 & 11.11 \\
\hline & $\mathrm{A} / \mathrm{A}$ & Homozygous & 1 & 3.70 \\
\hline \multirow{3}{*}{$\begin{array}{l}C Y P 1 A 2 * 1 D \\
(-1569 \text { delT) }\end{array}$} & $\mathrm{T} / \mathrm{T}$ & Wild-type & 19 & 70.37 \\
\hline & $\mathrm{T} / \mathrm{del}$ & Heterozygous & 0 & 0 \\
\hline & $\mathrm{del} / \mathrm{del}$ & HomozygousMutans & 8 & 29.63 \\
\hline \multirow{3}{*}{$\begin{array}{l}C Y P 1 A 2 * 1 E \\
(-155 \mathrm{~T}>\mathrm{G})\end{array}$} & $\mathrm{T} / \mathrm{T}$ & Wild-type & 5 & 18.52 \\
\hline & $\mathrm{T} / \mathrm{G}$ & Heterozygous & 22 & 81.48 \\
\hline & $\mathrm{G} / \mathrm{G}$ & Homozygous & 0 & 0 \\
\hline \multirow{3}{*}{$\begin{array}{l}C Y P 1 A 2 * 1 F \\
(-731 \mathrm{C}>\mathrm{A})\end{array}$} & $\mathrm{C} / \mathrm{C}$ & Wild-type & 0 & 0 \\
\hline & $\mathrm{C} / \mathrm{A}$ & Heterozygous & 21 & 77.78 \\
\hline & $\mathrm{A} / \mathrm{A}$ & Homozygous & 6 & 22.22 \\
\hline
\end{tabular}

not show theophylline levels above the therapeutic range (toxicity). There were even 3 people who showed levels of theophylline below the range of therapy but all of them showed improvement of the symptoms of asthma.(36)

The description between blood drug levels and CYP1A2 gene polymorphisms in the study subjects receiving intravenous aminophylline therapy can be seen in Table 5 and Table 6. In Table 5, the three subjects who had theophylline levels below the normal range $(<10 \mu \mathrm{g} /$ $\mathrm{mL}$ ) had del/del (mutant) allele of $C Y P 1 A 2 * 1 D$ and $\mathrm{A} / \mathrm{A}$ genotype (homozygous) of $C Y P 1 A 2 * 1 F$. The $C Y P 1 A 2 * 1 D$ gene polymorphism causes increased theophylline levels and the gene polymorphism in $C Y P 1 A 2 * 1 F$ causes a decrease in theophylline level. Table 4 shows the relationship between blood theophylline levels and $C Y P 1 A 2$ gene polymorphism in $C Y P 1 A 2 * 1 D, C Y P 1 A 2 * 1 E$ and $C Y P 1 A 2 * 1 F$ polymorphisms. Although there was a correlation between theophylline levels in the blood and the three polymorphisms, it is not yet possible to conclude which polymorphism was most influential on theophylline metabolism because the data retrieval was done only once and it did not illustrate the elimination of theophylline.

\section{Discussion}

The results of the study showed the effect of CYP1A2 genetic polymorphism in Indonesians. Although both are Asian races. these results are different from those conducted in Japan. According to Obase, et al., in the 
Table 5. Profile of theophylline in blood after administration of aminophylline for 1 hour with genetic polymorphism on all subjects receiving intravenous aminophylline therapy.

\begin{tabular}{|c|c|c|c|c|c|c|c|c|c|}
\hline \multirow{2}{*}{\multicolumn{2}{|c|}{$\begin{array}{l}\text { Theophylline Levels in Blood } \\
\qquad(\mu \mathrm{g} / \mathrm{mL})\end{array}$}} & \multicolumn{2}{|c|}{$C Y P 1 A 2 * 1 C$} & \multicolumn{2}{|c|}{$C Y P 1 A 2 * 1 D$} & \multicolumn{2}{|c|}{$C Y P 1 A 2 * 1 E$} & \multicolumn{2}{|c|}{$C Y P 1 A 2 * 1 F$} \\
\hline & & Genotype & $\begin{array}{l}\text { Types of } \\
\text { allele pairs }\end{array}$ & Genotype & $\begin{array}{l}\text { Types of } \\
\text { allele pairs }\end{array}$ & Genotype & $\begin{array}{l}\text { Types of } \\
\text { allele pairs }\end{array}$ & Genotype & $\begin{array}{l}\text { Types of } \\
\text { allele pairs }\end{array}$ \\
\hline 4.88 & below the normal range & $\mathrm{G} / \mathrm{G}$ & W & del/del & M & $\mathrm{T} / \mathrm{G}$ & $\mathrm{H}$ & $\mathrm{A} / \mathrm{A}$ & M \\
\hline 6.3 & below the normal range & $\mathrm{G} / \mathrm{G}$ & W & del/del & M & $\mathrm{T} / \mathrm{T}$ & W & $\mathrm{A} / \mathrm{A}$ & M \\
\hline 10.94 & in the normal range & $\mathrm{G} / \mathrm{G}$ & W & del/del & M & $\mathrm{T} / \mathrm{G}$ & $\mathrm{H}$ & $\mathrm{C} / \mathrm{A}$ & $\mathrm{H}$ \\
\hline 10.4 & in the normal range & $\mathrm{G} / \mathrm{A}$ & $\mathrm{H}$ & del/del & M & $\mathrm{T} / \mathrm{T}$ & W & $\mathrm{A} / \mathrm{A}$ & M \\
\hline 9.19 & below the normal range & $\mathrm{G} / \mathrm{A}$ & $\mathrm{H}$ & del/del & M & $\mathrm{T} / \mathrm{T}$ & W & $\mathrm{A} / \mathrm{A}$ & M \\
\hline 10.26 & in the normal range & $\mathrm{G} / \mathrm{A}$ & $\mathrm{H}$ & del/del & M & $\mathrm{T} / \mathrm{T}$ & W & $\mathrm{A} / \mathrm{A}$ & M \\
\hline 14.29 & in the normal range & $\mathrm{G} / \mathrm{G}$ & $\mathrm{W}$ & $\mathrm{T} / \mathrm{T}$ & $\mathrm{W}$ & $\mathrm{T} / \mathrm{G}$ & $\mathrm{H}$ & $\mathrm{C} / \mathrm{A}$ & $\mathrm{H}$ \\
\hline 12.5 & in the normal range & $\mathrm{A} / \mathrm{A}$ & M & del/del & M & $\mathrm{T} / \mathrm{T}$ & W & $\mathrm{A} / \mathrm{A}$ & M \\
\hline 10.5 & in the normal range & $\mathrm{G} / \mathrm{G}$ & W & del/del & M & $\mathrm{T} / \mathrm{G}$ & $\mathrm{H}$ & $\mathrm{C} / \mathrm{A}$ & $\mathrm{H}$ \\
\hline 12 & in the normal range & $\mathrm{G} / \mathrm{G}$ & W & $\mathrm{T} / \mathrm{T}$ & W & $\mathrm{T} / \mathrm{G}$ & $\mathrm{H}$ & $\mathrm{C} / \mathrm{A}$ & $\mathrm{H}$ \\
\hline 10.2 & in the normal range & $\mathrm{G} / \mathrm{G}$ & W & $\mathrm{T} / \mathrm{T}$ & W & $\mathrm{T} / \mathrm{G}$ & $\mathrm{H}$ & $\mathrm{C} / \mathrm{A}$ & $\mathrm{H}$ \\
\hline 13.2 & in the normal range & $\mathrm{G} / \mathrm{G}$ & W & $\mathrm{T} / \mathrm{T}$ & W & $\mathrm{T} / \mathrm{G}$ & $\mathrm{H}$ & $\mathrm{C} / \mathrm{A}$ & $\mathrm{H}$ \\
\hline 11.9 & in the normal range & $\mathrm{G} / \mathrm{G}$ & W & $\mathrm{T} / \mathrm{T}$ & W & $\mathrm{T} / \mathrm{G}$ & $\mathrm{H}$ & $\mathrm{C} / \mathrm{A}$ & $\mathrm{H}$ \\
\hline 10.4 & in the normal range & $\mathrm{G} / \mathrm{G}$ & W & $\mathrm{T} / \mathrm{T}$ & W & $\mathrm{T} / \mathrm{G}$ & $\mathrm{H}$ & $\mathrm{C} / \mathrm{A}$ & $\mathrm{H}$ \\
\hline 15.1 & in the normal range & $\mathrm{G} / \mathrm{G}$ & W & $\mathrm{T} / \mathrm{T}$ & W & $\mathrm{T} / \mathrm{G}$ & $\mathrm{H}$ & $\mathrm{C} / \mathrm{A}$ & $\mathrm{H}$ \\
\hline 13.3 & in the normal range & $\mathrm{G} / \mathrm{G}$ & W & $\mathrm{T} / \mathrm{T}$ & W & $\mathrm{T} / \mathrm{G}$ & $\mathrm{H}$ & $\mathrm{C} / \mathrm{A}$ & $\mathrm{H}$ \\
\hline 12.86 & in the normal range & $\mathrm{G} / \mathrm{G}$ & W & $\mathrm{T} / \mathrm{T}$ & W & $\mathrm{T} / \mathrm{G}$ & $\mathrm{H}$ & $\mathrm{C} / \mathrm{A}$ & $\mathrm{H}$ \\
\hline 12.59 & in the normal range & $\mathrm{G} / \mathrm{G}$ & W & $\mathrm{T} / \mathrm{T}$ & W & $\mathrm{T} / \mathrm{G}$ & $\mathrm{H}$ & $\mathrm{C} / \mathrm{A}$ & $\mathrm{H}$ \\
\hline 15.02 & in the normal range & $\mathrm{G} / \mathrm{G}$ & W & $\mathrm{T} / \mathrm{T}$ & W & $\mathrm{T} / \mathrm{G}$ & $\mathrm{H}$ & $\mathrm{C} / \mathrm{A}$ & $\mathrm{H}$ \\
\hline 14.37 & in the normal range & $\mathrm{G} / \mathrm{G}$ & W & $\mathrm{T} / \mathrm{T}$ & W & $\mathrm{T} / \mathrm{G}$ & $\mathrm{H}$ & C/A & $\mathrm{H}$ \\
\hline 13.55 & in the normal range & $\mathrm{G} / \mathrm{G}$ & W & $\mathrm{T} / \mathrm{T}$ & W & $\mathrm{T} / \mathrm{G}$ & $\mathrm{H}$ & $\mathrm{C} / \mathrm{A}$ & $\mathrm{H}$ \\
\hline 12.71 & in the normal range & $\mathrm{G} / \mathrm{G}$ & W & $\mathrm{T} / \mathrm{T}$ & W & $\mathrm{T} / \mathrm{G}$ & $\mathrm{H}$ & $\mathrm{C} / \mathrm{A}$ & $\mathrm{H}$ \\
\hline 13.52 & in the normal range & $\mathrm{G} / \mathrm{G}$ & W & $\mathrm{T} / \mathrm{T}$ & W & $\mathrm{T} / \mathrm{G}$ & $\mathrm{H}$ & $\mathrm{C} / \mathrm{A}$ & $\mathrm{H}$ \\
\hline 14.2 & in the normal range & $\mathrm{G} / \mathrm{G}$ & W & $\mathrm{T} / \mathrm{T}$ & W & $\mathrm{T} / \mathrm{G}$ & $\mathrm{H}$ & $\mathrm{C} / \mathrm{A}$ & $\mathrm{H}$ \\
\hline 17.1 & in the normal range & $\mathrm{G} / \mathrm{G}$ & W & $\mathrm{T} / \mathrm{T}$ & W & $\mathrm{T} / \mathrm{G}$ & $\mathrm{H}$ & $\mathrm{C} / \mathrm{A}$ & $\mathrm{H}$ \\
\hline 13.2 & in the normal range & $\mathrm{G} / \mathrm{G}$ & W & $\mathrm{T} / \mathrm{T}$ & W & $\mathrm{T} / \mathrm{G}$ & $\mathrm{H}$ & $\mathrm{C} / \mathrm{A}$ & $\mathrm{H}$ \\
\hline 12.6 & in the normal range & $\mathrm{G} / \mathrm{G}$ & W & $\mathrm{T} / \mathrm{T}$ & W & $\mathrm{T} / \mathrm{G}$ & $\mathrm{H}$ & $\mathrm{C} / \mathrm{A}$ & $\mathrm{H}$ \\
\hline
\end{tabular}

The normal range of blood theophylline levels is $10-20 \mu \mathrm{g} / \mathrm{mL}$. Allele pair type: $\mathrm{W}=$ wild; $\mathrm{H}=$ heterozygous; $\mathrm{M}=$ homozygous $/ \mathrm{mutants}$.

population of asthma patients in Japan $C Y P 1 A 2 * 1 C .(24)$ The $C Y P 1 A 2 * 1 D, C Y P 1 A 2 * 1 E$ and $C Y P 1 A 2 * 1 F$ were found. Another study in patients with lung cancer in Japan also found the four CYP1A2 polymorphic alleles.(37) A preliminary study of $C Y P 1 A 2 * 1 F$ polymorphism profiles in Java tribes in Indonesia showed that the frequency of the $C Y P 1 A 2 * 1 F$ gene in Indonesian population is greater than that of the population in Egypt, Japan and the UK, but lower than that of Malaysia.(30)

Profile of CYP1A2 allele effect on metabolism based on literature, includes $C Y P 1 A 2 * 1 C, C Y P 1 A 2 * 1 D$ and $C Y P 1 A 2 * 1 F$. The $C Y P 1 A 2 * 1 C$ has been shown to affect theophylline metabolism in Japanese patients with asthma. Theophylline clearance decreased significantly in asthma patients who had G/A or A/A genotype of CYP1A2*1C compared to the $\mathrm{G} / \mathrm{G}$ genotype. It has also been reported that high theophylline clearance values were significantly correlated with age in the G/G genotype.(24) The T allele of the CYP $1 A 2 * 1 D(\mathrm{~T} / \mathrm{T}$ or $\mathrm{T} / \mathrm{del})$ was associated with a decrease in the theophylline metabolism associated with increased CYP1A2 activity compared to the del/ del genotype, which means that gene polymorphisms in CYP $1 A 2 * 1 D$ alleles increase theophylline metabolism which causes increased theophylline levels in blood.(23) A 
Table 6. Cross-tabulation of $C Y P 1 A 2$ polymorphisms with theophylline levels in blood on sample research getting intravenous aminophylline intervention.

\begin{tabular}{|c|c|c|c|c|c|c|c|c|c|}
\hline \multirow{3}{*}{$\begin{array}{c}\text { Theophylline Levels } \\
\text { in Blood }\end{array}$} & \multicolumn{5}{|c|}{ CYP1A2*1C Gene Polymorphism } & \multicolumn{4}{|c|}{$C Y P 1 A 2 * 1 D$ Gene Polymorphism } \\
\hline & \multicolumn{4}{|c|}{$\mathbf{n}$} & \multirow{2}{*}{$p$-value } & \multicolumn{3}{|c|}{$\mathbf{n}$} & \multirow{2}{*}{$p$-value } \\
\hline & $\mathbf{G} / \mathbf{G}(\mathbf{W})$ & G/A (H) & $\mathbf{A} / \mathbf{A}(\mathbf{M})$ & Total & & del/del (M) & $\mathbf{T} / \mathbf{T}(\mathbf{W})$ & Total & \\
\hline Underdose & 2 & 1 & 0 & 3 & \multirow{4}{*}{0.415} & 3 & 0 & 3 & \multirow{5}{*}{$0.005^{*}$} \\
\hline Normal & 21 & 2 & 1 & 24 & & 5 & 19 & 24 & \\
\hline Overdose & 0 & 0 & 0 & 0 & & 0 & 0 & 0 & \\
\hline Total & 23 & 3 & 1 & 27 & & 8 & 19 & 27 & \\
\hline $\begin{array}{l}\text { The mean blood levels of } \\
\text { theophylline }(\mu \mathrm{g} / \mathrm{mL})\end{array}$ & 12.38 & 9.95 & 12.5 & & & 9.37 & 13.27 & & \\
\hline
\end{tabular}

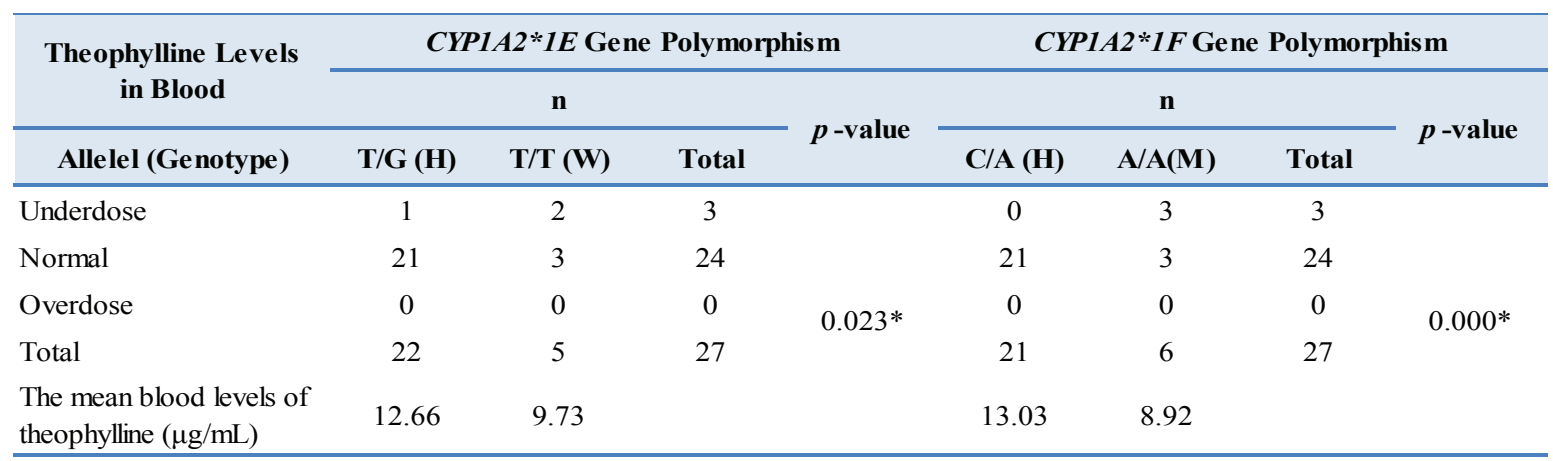

The normal range of blood theophylline levels is $10-20 \mu \mathrm{g} / \mathrm{mL}$. Allele pair type: $\mathrm{W}=$ wild; $\mathrm{H}=$ heterozygous; $\mathrm{M}=$ homozygous/mutants. $p$-value was obtained by chi-square test, *significant difference to theophyline levels.

allele of the $C Y P 1 A 2 * 1 F$ is a faster metabolizer compared to $\mathrm{C}$ allele. Therefore, the A/A genotype of $C Y P 1 A 2 * 1 F$ has a faster metabolism than $\mathrm{C} / \mathrm{C}$ or $\mathrm{C} / \mathrm{A}$, leading to lower drug levels.(31) Theophylline is metabolized in the liver using the P450 cytokrom enzyme and its metabolism is affected by the CYP1A2 enzyme.

This study has some limitations, first one is the types of asthma phenotype. According to Asthma Management Handbook there is a strong association between asthma and allergies. and over $80 \%$ of asthmatics have allergic sensitivities. These allergies trigger the onset of asthma exacerbations. So patients should avoid allergic exposure to keep their asthma under control because there is a strong association between asthma and allergies that is more than $80 \%$ of asthmatics have allergic sensitivity.(32) The effect of asthma type will be need to be discussed with the response to corticosteroid therapy. In allergy types, asthma provides a better response to corticosteroid therapy than non-allergic asthma.(1) However, since all subjects did not use additional corticosteroid therapy, so the type of asthma did not affect the results of the study. The second limitation is the race of participant. The research subjects were of mixture of different ethnic, and it was hard to correspond the genetic polymorphism found in this study to any specific ethnic/ race. And the last one is the long observation of theophylline level in blood. Examination of theophylline level in blood was done only once. one hour after aminophylline therapy. Therefore it was not known how large was the influence of CYP1A2 gene polymorphism on metabolism and profile of theophylline excretion in blood.

\section{Conclusion}

In this study, the most heterozygous genotypes found were the $\mathrm{T} / \mathrm{G}$ genotype of $C Y P 1 A 2 * 1 E$ and the C/A genotype of $C Y P 1 A 2 * 1 F$, whereas the most homozygous genotype was the $\mathrm{G} / \mathrm{G}$ genotype of $C Y P 1 A 2 * 1 C$ and $\mathrm{T} / \mathrm{T}$ genotype of CYP1A2*1C. Most homozygoues alleles exist in $C Y P 1 A 2 * 1 D$ in the form of del/del genotipe and CYP $1 A 2 * 1 F$ in the form of $\mathrm{A} / \mathrm{A}$ allele. Meanwhile in polymorphism $C Y P 1 A 2 * 1 E$ no homozygous allele $(\mathrm{G} / \mathrm{G})$ was found. There was a relationship between blood theophylline levels and CYP1A2 gene polymorphism in CYP1A2*1D, CYP1A2*1E and $C Y P 1 A 2 * 1 F$ polymorphisms. Identification of $C Y P 1 A 2$ gene polymorphism can support asthma treatment in predicting theophylline therapeutic effect so as to prevent adverse drug reactions and appropriate dose adjustments. 


\section{References}

1. Global Initiative for Asthma (GINA). Global Strategy for Asthma Management and Prevention (Update). [No Location]: GINA; 2018.

2. National Asthma Education and Prevention Program. Guidelines for the diagnosis and management of asthma. Expert Panel Report 3. Maryland: National Institutes of Health and National Heart Lung and Blood Institute; 2007.

3. She J, Johnston M, Hays RD. Asthma outcome measures: asthma exacerbation. Expert Rev Pharmacoeconomics Outcomes Res. 2011; 11: 447-53.

4. Kementrian Kesehatan Republik Indonesia. Keputusan Menteri Kesehatan Republik Indonesia Nomor 312/MENKES/SK/ IX/2015 tentang Daftar Obat Essensial 2015. Jakarta: Kementerian Kesehatan Republik Indonesia; 2015.

5. Kementrian Kesehatan Republik Indonesia. Keputusan Menteri Kesehatan Republik Indonesia Nomor HK.02.02/ MENKES/523/2015 tentang Formularium Nasional. Jakarta: Kementerian Kesehatan Republik Indonesia; 2015.

6. Travers AH, Jones AP, Camargo CA, Milan SJ, Rowe BH. Intravenous beta(2)-agonists versus intravenous aminophylline for acute asthma. Cochrane Database Syst Rev. 2012; 12: CD010256. doi: 10.1002/14651858.CD010256.

7. Roberts G, Newsom D, Gomez K, Raffles A, Saglani S, Begent J. Intravenous salbutamol bolus compared with an aminophylline infusion in children with severe asthma: a randomised controlled trial. Thorax. 2003; 58: 306-10.

8. Xu YJ. Development of theophylline in treatment of asthma and chronic obstructive pulmonary disease. Zhongguo Yi Xue Ke Xue Yuan Xue Bao. 2004; 26: 319-22.

9. Lorensia A, Wahjuningsih E, Canggih B, Lisiska N. Pharmacist's strategies in treating asthma bronchiale outpatient. J Trop Pharm Chem. 2011; 1: 177-91.

10. Lorensia A, Wahjuningsih E, Supriadi. keamanan penggunaan aminophylline pada asma di rumah sakit delta surya sidoarjo. Indones J Clin Pharm. 2012; 1: 154-61.

11. Lorensia A, Canggih B, Wijaya RI. Analisa adverse drug reactions pada pasien asma di suatu rumah sakit Surabaya. Jurnal Farmasi Indonesia. 2013; 6: 142-50.

12. Lorensia A, Amalia RA. Studi farmakovigilans pengobatan asma pada pasien rawat inap di suatu rumah sakit di bojonegoro. Jurnal Ilmiah Manuntung. 2015; 1: 8-18.

13. Lorensia A, Ikawati Z, Andayani TM, Maranatha D, Wahjudi M. Comparison of electrolyte disturbance of using intravenous aminophylline versus nebulization salbutamol for exacerbation asthma in Surabaya Indonesia. Int J Pharm Clin Res. 2016; 8: 221-8.

14. Rugelj N, Trobec KC, Pišlar M, Brguljan PM, Košnik M, Mrhar A. Evaluation of theophylline therapeutic drug monitoring service. Zdrav Vestn. 2015 ;84: 191-202.

15. Hart SP. Should aminophylline be abandoned in the the treatment of acute asthma in adults? Q J Med. 2000; 93: 761-5.

16. Parameswaran K, Belda $\mathrm{J}$, Rowe $\mathrm{BH}$. Addition of intravenous aminophylline to beta2-agonists in adults with acute asthma. Cochrane Database Syst Rev. 2000; 4: CD002742. doi: 10.1002/14651858.CD002742.

17. Fotinos $\mathrm{C}$, Dodson $\mathrm{S}$. Is there a role for theophylline in treating patients with asthma? Family Practice Inquiries Network. 2002; 51: [np].
18. Makino S, Adachi M, Ohta K, Kihara N, Nakajima S, Nishima S, et al. A prospective survey on safety of sustained-release theophylline in treatment of asthma and COPD. Allergol Int. 2006; 55: 395-402.

19. Tyagi N, Gulati K, Vijayan VK, Ray A. A study to monitor adverse drug reactions in patients of chronic obstructive pulmonary disease: focus on theophylline. Indian J Chest Dis Allied Sci. 2008; 50: 199202.

20. Tse SM, Tantisira K, Weiss ST. The pharmacogenetics and pharmacogenomics of asthma therapy. Pharmacogenomics J. 2011; 11: 383-92.

21. Fenech AG, Grech G. Pharmacogenetics: where do we stand? J Malta Coll Pharm Pract. 2011; 11: 25-33.

22. Baba K, Yamaguchi E. Issues associated with stepwise management of bronchial asthma. Allergol Int. 2005; 54: 203-8.

23. Uslu A, Ogus C, Ozdemir T, Bilgen T, Tosun O, Keser I. The effect of CYP1A2 gene polymorphisms on Theophylline metabolism and chronic obstructive pulmonary disease in Turkish patients. Biochem Mol Biol Rep. 2010; 43: 530-4.

24. Obase Y, Shimoda T, Kawano T, Saeki S, Tomari SY, Mitsuta-Izaki $\mathrm{K}$, et al. Polymorphisms in the CYP1A2 gene and theophylline metabolism in patients with asthma. Clin Pharmacol Ther. 2003; 73: 468-74.

25. Yasuda SU, Zhang L, Huang SM. The role of ethnicity in variability in response to drugs: focus on clinical pharmacology studies. Clin Pharmacol Ther. 2008; 84: 417-23.

26. Belle DJ, Singh H. Genetic factors in drug metabolism. Am Fam Physician. 2008; 77: 1553-60.

27. Johnson JA. Ethnic differences in cardiovascular drug response: potential contribution of pharmacogenetics. Circulation. 2009; 118: 1383-93.

28. Yue QY, Svensson JO, Alm C, Sjoqvist F, Sawe J. Interindividual and interethnic differences in the demethylation and glucuronidation of codeine. Br J Clin Pharmacol. 1989; 28: 629-37.

29. Zhou HH, Sheller JR, Wood M, Wood AJ. Caucasians are more sensitive than Chinese to the cardiovascular and respiratory effects of morhipne but less to the gastrointestinal side effects. Clin Res. 1990; 38: 968A.

30. Queljoe DD, Wahjudi M, Erdiansyah M, Suryadinata RV, Lorensia A. Studi pendahuluan polimorfisme genetik gen cypla $2 * 1 \mathrm{f}$ pada pasien asma dan non-asma di Indonesia. Indones J Clin Pharm. 2014; 4: 8-16.

31. SNPedia [Internet]. rs762551 [cited 2016 Aug 2]. Available from: https://www.snpedia.com/index.php/Rs762551.

32. National Asthma Council Australia. Asthma Management Handbook. Melbourne: National Asthma Council Australia; 2006.

33. Fong N. Aminophylline/Theophylline: Loading and maintenance dose. Norwich: NHS Trust - East Lancashire Hospitals; 2011

34. Scottish Intercollegiate Guidelines Network. British Guideline on the Management of Asthma. Edinburgh: British Thoracic Society; 2011.

35. Singh AS, Masuku MB. Sampling techniques \& determination of sample size in applied statistics research: an overview. Int J Economics Commerce Manag. 2014; 2: 1-22.

36. Lorensia A, Ikawati Z, Andayani TM, Suryadinata RV, Hartoro KAA, Firanita LD. Efektifitas dan risiko toksisitas aminofilin intravena pada pengobatan awal serangan asma efektifitas dan risiko toksisitas aminofilin intravena pada pengobatan awal serangan asma. Indones J Clin Pharm. 2018; 7: 78-88.

37. Chida M, Yokoi T, Fukui T, Kinoshita M, Yokota J, Kamataki T. Detection of three genetic polymorphisms in the 5 '-flanking region and intron I of human CYP1A2 in the Japanese population. Jpn J Cancer Res. 1999; 90: 899-902. 